\title{
Franz Beranek and his activities in Slovakia ${ }^{1}$
}

\author{
Tomáš Kubisa
}

PhDr. Tomáš Kubisa

Slovak Academy of Sciences

Institute of Ethnology and Social Anthropology

Klemensova 19

81364 Bratislava 1

Slovakia

e-mail: tomas.kubisa@savba.sk

Mureológia a kultúrne dedičstvo, 2020, 8:2:77-89

DOI: $10.46284 / \mathrm{mkd} .2020 .8 .2 .5$

Franz Beranek and his activities in Slovakia

This paper deals with the research of Prof Franz Josef Beranek focused on the so called "Habans", a social religious group that settled in western Slovakia. This research is reconstructed according to the so called German Archive, which forms a part of the scientific collections of the Institute of Ethnology and Social Anthropology of the Slovak Academy of Sciences. The first part is focused on the life of Franz Beranek and his research on the Haban community, including the history, the linguistic situation, and comparisons to other Anabaptist groups. The second part deals with the procedure of cataloguing the archive and its history, structure, and issues.

Keywords: Habans, Franz Josef Beranek, Anabaptists, The German Archive, Mennonites, Hutterites, Third Reich, Dialect

Although Franz Josef Beranek is not one of the leading names in the world of academia and is not very well known at the other end of the moral spectrum, as a Nazi academic, his work has gained a permanent place in German linguistics and, as I will point out in this article, also in Slovak ethnology.

Franz J. Beranek was born in 1902 in today's Břeclav. He attended (from first to fourth year) the German People's School, which he later considered to be the key event in the forming of his own sense of national belonging. He graduated from the German grammar school in 1920. He entered the German Technical University in Brno, but later moved to German and Slavonic studies in Vienna (1921) and in 1923 he switched to the German University in Prague. After defending his doctoral thesis, ${ }^{2}$ he graduated as a Doctor of Philosophy in 1932. Until the 1940s he worked as a secondary school teacher. ${ }^{3}$ In his academic interest, Beranek focused on researching German dialects (where he also included the Yiddish language) in the environment of German minorities abroad, but was also interested in ethnographic topics. From 1926 to 1928 he lived in Břeclav and, under the influence of growing German nationalism, devoted himself to public education and journalism. Despite his "Germanhood", he was tied to his home in South

${ }^{1}$ This article was supported by the project Folklore, folkloristics and ideology, VEGA 2/0107/19 (2019 - 2022).

${ }^{2}$ Die deutsche Mundardt von Südmähren (Vocalism) (German dialects of South Moravia [Vocalism]).

${ }^{3}$ PANCZOVÁ, Zuzana. Pôsobenie Franza J. Beranka na Slovensku v 30.a 40. rokoch 20. storočia: výskum „Huncokarov“a InstituAt für Heimatforschung. In: Ethnologia Europae Centralis. Trnava: 2017, p. 26. 
Moravia, and much work is devoted to this area. It was during this period that he visited the German enclaves in various parts of Czechoslovakia, including the Huncokars. German ethnographers working at the German University in Prague considered the studying of German enclaves an important part of German ethnography in Czechoslovakia. ${ }^{4}$ Most of his research trips in Slovakia (to visit Huncokars ${ }^{5}$ ) took place in 1928. In his works from this period he drew attention to the disappearing German settlements and called for protection against assimilation into the Slovak majority. His most important work of this period is "Die deutsche Besiedlung der Westslowakei" (German Settlement of Western Slovakia; Beranek 1943). In 1941 Beranek was installed as a lecturer for the German Homeland Association in Slovakia. ${ }^{6}$ The material from the research carried out in Slovakia became part of the archive fund of the Institut für Heimatforschung in Kežmarok (IHF). Its operation was inaugurated on 22 March 1941. The IHF's aim was academic as well as educational activities for the benefit of the German minority along the lines of the Third Reich's cultural institutions, towards the unification of the German population throughout Southeastern Europe. ${ }^{7}$

Beranek was initially active as a scientific adviser, and later as the head of the language research department. This department dealt with the documentation and creation of a card register of German terms in the Slovak language, German settlements in Slovakia, and German historical documents and dialects. In its report, the Institute für Heimatforschung mentions research on the Huncokar and Haban communities, drawing attention to the collaboration of Beranek with his wife, Hertha Wolf-Beranek, in the study of already defunct German settlements. The plans of this department reveal works on the dialect of the Bratislava area, the dialect of Huncokar settlements, the dialect of the Haban community, and a detailed description of German surnames. A detailed list of the German names of all Slovak municipalities was in the process of preparation, and was intended for the needs of the Deutsche Partei. Since the beginning of its activities, it had been clearly defined that the scientific data collected and archived by the association would be used not only for academic but also for practical purposes. ${ }^{8}$ At the turn of the years 1943 and 1944, the Beranek's activities in the IHF in Kežmarok came to an end after a conflict with Johann Lipták (leader of the IHF) and the couple returned to the Protectorate, to the town of Déčín. An interesting link between the activities of the Beranek family and Slovak ethnology is the fact that Hertha-Wolf, in collaboration with her husband, drafted an opinion on the work of Rudolf Bednárik,

\footnotetext{
${ }^{4}$ LOZOVIUK, P. (ed).Etnicita a nacionalismus v diskursu 20. století. Brno: 2012.

${ }^{5}$ Lumberjacks of German and Austrian descent living in the Small Carpathians.

${ }^{6}$ HUTTON, CH. Linguistics and the Third Reich: Mother Tongue Fascism, Race and the Science of Language. London: 2014, p. 213.

${ }^{7}$ SCHVARC, Michal. „Kulturraub“ alebo záchrana kultúrneho dedičstva? Evakuácia archívov a kultúrnych pamiatok nemeckými orgánmi zo Slovenska koncom2. svetovej vojny. In: Muzeológia a kultúrne dedičstvo, vol. 1, 2013, No. 1, p. 77.

${ }^{8}$ PANCZOVÁ, Pôsobenie Franza J. Beranka... p. 30.

${ }^{9}$ Leading Slovak ethnologist, considered one of the "founding fathers" of Slovak ethnology. In his research and publishing activities he devoted himself to folk architecture and housing, folk art, folk customs, and employment, as well as Slovaks abroad. His work constitutes a special proof of an important stage in the development and formation of Slovak ethnology. He has published 18 monographs, eg. Spiritual and Material Culture of the Slovak People (In: Slovenská vlastiveda, 1943), Folk Tombstones in Slovakia (1949), Painted Fireplaces in the Small Carpathians (1956), Slovaks in Yugoslavia (1964), Folk Architecture in Kysuce (1967), Slovakia (1972), and over 70 expert studies and articles. He participated in the education of a whole generation of Slovak ethnologists. Bednárik, Rudolf [online]. Encyclopaedia Beliana, ISBN 978-80-89524-30-3. [Cit. 2020-03-31]. Available on the Internet: https://beliana. sav.sk/heslo/bednarik-rudolf
} 
Slovakische Volkskultur (Slovak Folk Culture), in which she reproaches the author for not taking into account the influence of "Germanhood" on Slavic and Slovak culture. ${ }^{10}$ Towards the end of the war, Beranek fled back to Germany, but during this escape, most of his work (and probably part of the archive mentioned here) was lost. He reconstructed it with limited success. After his death, his wife Hertha Wolf-Beranek was to continue this project. After the war, he went through a denazification process and started to work the university again. However, his position was complicated, some of his colleagues considering him a "Nazi scientist" despite denazification and refusing any cooperation, but for good reason. He joined the NSDAP only in 1938 (later defending himself by stating that it was due to professional pressure), but was also a member of the paramilitary SA (Sturmebteilung), and his wife Hertha Wolf-Beranek was a member of Ahnenerbe and SS organisations. He profited from the Nazi regime. He worked his way up from secondary school teacher to associate professor at Charles University in Prague in 1944. In his defence, it may be noted that Max Weinreich does not mention him in his publication Hitler's Professors, which can only suggest that he did not consider him a sufficiently important "academic-criminal". Beranek also tried to make contacts with Jewish scholars in his post-war career through his interest in Yiddish. All of this would indicate that Beranek was more opportunist than a convinced Nazi. ${ }^{11}$

\section{Franz Beranek and the "Anabaptist Question"}

The name "Habans" in Slovakia refers to members of the social-religious movement of Anabaptist groups (neo-Baptists). In the following lines I will briefly discuss the prevalent views on the origins and ethnicity of the Habans.

The emergence of neo-Christian movements was a direct consequence of the Reformation. More precisely, the Anabaptists were among those of the radical reformist wing, which criticised the reformist movement. In 1524, supporters of this wing met at a meeting in the city of Zurich and asked the authorities for an open dispute with the preachers of the city, where they wanted to act as a new church in public. They proclaimed the need for baptism in adulthood and the implementation of Bible-based social principles in life, bringing them closer to the first Christian communities and achieving a higher degree of moral and religious excellence. In 1525, this public dispute ended with the defeat of the Anabaptists and the declaration by the city council for the obligatory baptism of children. Opponents of this order could leave the city and the country with their families and property. The gradual migration of Anabaptists led them through neighbouring countries, especially the territory of the German states, Tyrol, and Italy. ${ }^{12}$

Anabaptists came to Moravia under the leadership of Baltahazar Hubmeier, who settled in Mikulov and founded a printing house through which he spread his teachings and ideas of Anabaptism. On the direct order of the imperial court in Vienna he was arrested and executed by burning as a heretic.

The consolidation of Anabaptism as a social movement in Moravia was largely due to Jakub Huter, who enforced common ownership, and a radical condemnation of private ownership as the greatest sin against God. Some Anabaptists disagreed with this radicalisation, and two opposing groups were formed. Followers of Huter began to be nicknamed the Huterites. The

\footnotetext{
${ }^{10}$ PANCZOVÁ, Pôsobenie Franza J. Beranka..., pp 32-33.

${ }^{11}$ KALMAN, Weiser: "One of Hitler's Professors": Max Weinreich and Solomon Birnbaum confront Franz Beranek. In: Jewish Quarterly Review 108, 2018, pp. 106-124.

${ }^{12}$ KALESNÝ, František and SZABÓ, Tibor. Habáni na Slovensku. Bratislava: Tatran, 1981, pp. $13-15$.
} 
contradictions deepened and repressions by the state and Catholic Church intensified. Huter was burnt in 1536. The Moravian aristocracy, however, used the knowledge and diligence of the Anabaptists despite the reluctance of the royal court. However, the pressure intensified and, on the direct order of the emperor (through Cardinal Dietrichstein), the Anabaptists of Moravia were expelled under pain of death. The core of the Anabaptist movement thus shifted to the Kingdom of Hungary, to the territory of present western Slovakia. ${ }^{13}$

The next fate of the Habans was grim: the Thirty Years' War and the Ottoman-Habsburg wars left great damage on brothers' courts. Over time, the Habans switched to a private farming system and were re-Catholicised and merged with the native population. Some of these groups emigrated to Transylvania, from there to the territory of czarist Russia, and later to the American continent. ${ }^{14}$

In spite of the unity of this group at first glance, it cannot be stated that it was a homogeneous group or a group of common origin. The establishment of groups in Slovakia was continuous. Anabaptists of Tyrolean descent made up the the core of the Haban communities, but the chronicles also mention those of Bavarian, Swabian, Swiss, Silesian, Hessen, Rhine, and even Italian, Moravian and Slovak origins. The social status of the Habans (not being vassals of the king and having a higher standard of living) also ensured the supply of members from the ranks of the domestic population. ${ }^{15}$

In view of the fact that the research interests of Franz Beranek were mainly linguistic, it is appropriate to look at some etymological theories about the word "Haban", as the neo-Baptists were referred to by the majority of the Slovak population.

The etymology of the word "Haban" is unclear, but there are several theories. The most commonly mentioned theory is the so-called German origin theory, predominantly citing derivation from the word "baushaben". ${ }^{16}$

Other opinions claim that this is a garbled version of the word "hannoveraner" (Hanoverian).

The Habans, however, did not use this name, and considered it disrespectful at best, and offensive at worst. However, this word has already penetrated literature and has also become a toponym. In 1810, Alojz Medňanský formulated the theory that the Anabaptists had also brought a distinct dialect_ "Plattdeutsch" (a group of North German dialects, a mixture of dialects spoken in their homeland). This theory has been repeated several times. In the 1930s Oto Haban, a descendant of Haban immigrants, explored the dialect area and found it bounded by the confluence of the rivers Moravia and Myjava. On the left bank of river Myjava this name is used very little, suggesting that it was not a widespread word for this group, and that it became generally known later.

Other opinions derive the name from the word "Hofan", i.e., a resident of the court or an Anabaptist (anabtan)..$^{17}$

It can, however, be stated that the word Haban is purely Slovak, because the first written record in Slovakia is from 1667. The most probable seems to be the theory of Bratislava city archivist Ovídius Faust, according to which the word Habán comes from the word "babat"

\footnotetext{
${ }^{13}$ KALESNÝ and SZABÓ, Habáni..., pp. 16-18.

${ }^{14}$ KALESNÝ and SZABÓ, Habáni..., pp. 77-92.

${ }^{15}$ KALESNÝ and SZABÓ, Habáni..., p. 46.

${ }^{16}$ ČERNOHORSKÝ Karel. Počátky habánskych fajansí. Opava, 1931, s. 7.

${ }^{17}$ KALESNÝ and SZABÓ, Habáni..., pp. 8-12.
} 
or "zhabat" (meaning to confiscate) and it refers to people who have had their property confiscated, which often happened to Anabatist groups. ${ }^{18}$

There is also a relatively exotic theory of etymological interpretation by Gustav Weiss, who derived this name from the Hebrew "ba-banim", meaning the true children of God, who the Anabaptists thought themselves to be, but as I mentioned, the term Haban was perceived as offensive. At the present time, this word is generally accepted and has no negative meaning. ${ }^{19}$

This brief linguistic and historical excursion was necessary in order to understand what led Prof. Beranek to be interested in the Habans. In the following lines I will analyse the structure of the Haban part of the scientific collection known as the "German Archive" and try to reconstruct the course of the research of this socio-religious group. When we look at the existing digital catalogue, we find that the documents can be divided into the following six categories:

1.) Questionnaires for dialect research (Mundartlicher Fragebogen)—mainly focused on terms from botany, zoology, architecture, agriculture, and family terminology. The questionnaires have a uniform structure, each box containing the word in standard German and dialectological examples. In case it was necessary to find out several names of individual parts of the object, the questionnaires also contain a picture of the object. Questionnaires are filled only to a small extent.

2.) Correspondence-mostly answers to Franz Beranek's letters from various researchers in the field of Anabaptist groups.

3.) Excerpts - bibliographic data on literature related to Habans and Anabaptists in the world. Both domestic (Slovak and Czech) and foreign publications are present.

4.) Dialectological notes - this is the most extensive part of the Haban part of the archive, unfortunately scientifically almost worthless because of the lack of data on the location of dating and etymology of the term.

5.) Library cards-books mostly from the then Slovak University in Bratislava, whose lender was Franz Beranek.

6.) Topographical names (Ortsnamen) - contains topographical names mostly from the Záhorie region. The vast majority of toponyms are in German with marked pronunciation, but Slovak names of municipalities are also present.

I will now analyse the correspondence in detail, which is the most content-relevant. Franz Beranek's interest in the Habans was primarily linguistic, trying to record the dialects spoken by these groups of the population. A cross-section of the archives proves the preparation for and the start of such research, but it is unclear whether Beranek also underwent field research and visited the sites mentioned in his archive. However, this is not excluded because, demonstrably, he underwent an expedition to the Huncokars in the Little Carpathian Mountains and the Haban settlement was not so far away.

Beranek contacted other researchers in the field of Anabaptism, in particular the Austrian philosopher and historian, Robert Friedmann (1891-1970), with whom he continued a lively correspondence (from 1932 to 1933). Beranek was particularly interested in the Anabaptist

${ }^{18}$ FAUST Ovidius. Zo starých zápisníc mesta Bratislavy. Bratislava: Universum, 1933 p. 176.

${ }^{19}$ KALESNÝ and SZABÓ, Habáni..., p. 12. 
communities on the American continent, especially the Hutterites in Canada. Friedmann wrote to him:

I don't think any profits will come from correspondence with the Huterite brothers in Canada. The brothers do not communicate with foreigners very much and their answers are usually short and unpleasant. They are against pure science (and in your case they are very suspicious). They only allow historical research to illuminate their past. But you can try your luck and write. ${ }^{20}$

Friedmann gave valuable advice to Beranek about the resources, advising him who to contact or which institutions to visit for research. Beranek also asked about the situation regarding Anabaptists in Transylvania (Siebenbürgen), but he received an answer that the communities were there, but that they had probably already assimilated. He wrote that he knew nothing about the situation in Ukraine, but that it was possible that there were remains of these settlers.

However, he also provided him with knowledge from his own research and study trips. He also describes his visit to Vel'ké Leváre:

During my visit, I spoke to an older woman who spoke an old "habanian dialect", which is almost lost, and I noticed the word "erchtag" or "Iritag" for Tuesday (Dienstag). This is really a word from the old Germanic collection. ${ }^{21}$

In Beranek's texts, published in the 1920s and 1930s, he explores romantic ideas of language and nation and expresses a strong need to draw attention to the protection of the disappearing German settlements against assimilation into the ethnic majority. ${ }^{22}$

Obviously, Beranek tried to get samples of all the dialects that these Anabaptist groups could speak. There is no direct correspondence between Beranek and the Anabaptist communities (anywhere) in this archive collection, suggesting that they refused cooperation.

Friedmann assisted him both in this research, sending him publications about the Anabaptists in the USA and Canada, and in the correspondence he himself led with these communities (again with warning that the "profit" from them would be low). However, Friedmann strongly reminds him not to forget to return them, as he archives all letters. Studying the old Hutterite manuscripts could bring him greater benefits. ${ }^{23}$

Apparently, Beranek urged for contact to be made with the Anabaptist communities, because in the next letter of 1932 the following answer is given:

Addressing the brothers in Canada would make no sense, because I know that brothers are very secretive unless they feel special religious interests or historical research. They have less understanding for linguists. Of course, the brothers are very closely related to the Mennonites, they are actually part of them, namely the Communist part, and they are in direct contact with the relatively strong Mennonite Church. ${ }^{24}$

\footnotetext{
${ }^{20}$ German archive IESA SAS, $V$ - Habanerisch - 1932, Vienna, Robert Friedmann, document no. 9.

${ }^{21}$ German archive IESA SAS, $V$ - Habanerisch - 1932, Vienna, Robert Friedmann, document no. 9.

22 PANCZOVÁ, Pôsobenie Franza J. Beranka..., p. 27.

${ }^{23}$ German archive IESA SAS, $V$ - Habanerisch - 1932, Vienna, Robert Friedmann, document no. 10.

${ }^{24}$ German archive IESA SAS, $V$ - Habanerisch - 1932, Vienna, Robert Friedmann, document no. 11.
} 
Friedmann also advises him to contact official institutions such as the Mennonite historical society in Goshen, Indiana, USA. ${ }^{25}$ However, this correspondence is missing from the archive, so either it did not happen at all, or the institution did not respond to the letter.

Concerning the Hutterite linguistic research, he suggests contacting Dr Eberhard Arnold, the leader of the Hutterite Brotherhood in Germany. Other researchers Friedmann recommends contacting are: Berta W. Clark, who had lived for four weeks between brothers in Canada; and Dr Macourek and Dr Novotný, both of whom had published in the Vèstník uéené spolecnosti (Bulletin of the Scholarly Society; 1929).

Interesting also is the development of the relationship between Beranek and Friedmann. In early letters Beranek is addressed "Dear (honoured) Professor" (Hochverehrter Herr Professor), then in the next few letters "Dear Colleague" (Sehr geehrter Herr Kollege) and then in later letters Friedmann addressees him "Dear friend" (Lieber Freund).

Friedmann also sent Beranek the words he discovered to aid him in building his expertise, and almost every letter concludes with a wish for research success and adds how he looks forward to publishing the results.

In the following letter from 1933 there is also an interest in ethnographic topics:

I also must thank you for the beautiful photographs that once again reminded me of the dear houses, their cleanliness and internal order. They are indeed symbols of the population, at least from the past.

The fact that there are still remnants of the Habans in Levars, also remnants of their former community life, is remarkable. When I was there in 1925, I met only a few "remains" which is a great pity. ${ }^{26}$

Photos of Haban ceramics are also mentioned, but again these are missing from the archive collection. The letter also mentions the name of a family who emigrated from Sobotište to Canada. Friedmann complains in his letter that his work is stagnant and that his publishing options are limited. ${ }^{27}$

On the issue of Anabaptism in south-eastern and eastern Europe, Beranek made less effort to obtain data. There are only two letters in the archive concerning this. The first is from Prof Viktor Schirminsky, who describes the colony of Huttertall in Ukraine near the town of Melitopol. At the same time, however, he adds that its inhabitants moved to Canada and that today there are only the remains of a former colony. ${ }^{28}$ For more information, he recommends studying literature, namely Alexander Klaus-Our Colony of Odessa (Unsere Kolonien Odessa, 1887) - or contact the German Foreign Institute-Deutsches Ausland Institut Stuttgart. Beranek did so and received a brief reply:

\footnotetext{
${ }^{25} \mathrm{It}$ is still a functioning institution, founded in 1924. It is dedicated to promoting Mennonite/Anabaptist history and the everyday life of this community. Source: https://mennonitehistoricalsociety.org/about/ accessed 25 September 2019.

${ }^{26}$ German archive IESA SAS, $V$ - Habanerisch - 1932, Vienna, Robert Friedmann, document no. 12.

${ }^{27}$ The letter is dated June 1933. In January of that year, Adolf Hitler became the chancellor of Germany, and it is likely that it alludes to a change of circumstances. The situation was complicated because Friedmann was of Jewish origin.

${ }^{28}$ German archive IESA SAS, $V$ - Habanerisch - 1932, Sudak, Viktor Schirminski, document no. 7.
} 
We inform you that the Communist sect of the Hutterites lived in Romania until 1770 and in southern Russia between 1770 and 1774. Then they emigrated to the USA (South Dakota and Montana) and to the prairie provinces of Canada. So you will not find Hutterites to have been in Romania since 1770 and since 1874 not even in southern Russia. The followers of the Hutterites, called Habans, enjoyed special religious privileges and still live in Sobotište and the Vel'ké Leváre, but they are now members of the Roman Catholic Church. Whether they have retained their Hutterite identity, is beyond our knowledge.

In 1926, a fraternal communist settlement was established in Germany near the town of Fulda under the leadership of Dr Eberhard Arnold and in 1930 they formally joined the Hutterite sect. ${ }^{29}$

It is likely that sometimes Beranek received contradictory information, as was made possible by the fact that most of the data was based on theoretical research, real usable material being scarce. Beranek tried to fill this gap by contacting every researcher who had merely mentioned the word Haban somewhere. The proof is listed in a letter from the Czech art historian Václav Vilém Štech, where he explains that he did not deal with the Habans and their faith and that the article Beranek had taken interest in "was improvised on the request of the editorial board, not supported by scientific studies" and was "pure journalism, without scientific ambition." 30

The only real field research report comes from Johann Winter, who visited Sobotište and sent a report to Beranek briefly describing the functioning of the Haban court:

I won't tell you anything new; once a year, a week after the festival of the Three Kings, they have a meeting, all members of the fraternity are the owners of the Haban courts, 40 board members select the head of the board and two senior officials. The following festivities will be held on January 12 at the Brotherhood's guest house. ${ }^{31}$

In addition to the social order, he also briefly comments on the Haban dialect:

The inhabitants of Sobotište know almost nothing, they speak only a little German, almost no "Haban" at all. Only one older man had the courage and said "Gackerle" instead of an egg (Eier), and that is the only Haban word I have heard here. ${ }^{32}$

The letter also mentions that he had also sent a copy of the sixteenth century Haban chronicle, that the original had allegedly been stolen with a copy made by the local priest, that the mayor might have had interesting information, but that he didn't want to show anything. Regarding Vel'ké Leváre, it is mentioned here that:

\footnotetext{
${ }^{29}$ German archive IESA SAS, $V$ - Habanerisch - 1932, Sudak, Heinz Kloss, document no. 48.

${ }^{30}$ German archive IESA SAS, $V$ - Habanerisch - 1932, Sudak, Václav Vilém Štech, document no. 49.

${ }^{31}$ German archive IESA SAS, $V$ - Habanerisch - 1932, Sudak, Johann Winter, document no. 51.

${ }^{32}$ German archive IESA SAS, $V$ - Habanerisch - 1932, Sudak, Johann Winter, document no. 51.
} 
The Vel'ké Leváre are interesting; until recently there were German schools. I recorded some Haban words: - Tuesday (Dienstag) - "Erchtig", Friday (Freitag) - "Pfingstig, Apron (schürze) - "Huter", Shirt (hemd) - "Pfad", Chimney sweep (Kaminfäger) - Kemetschore, Ich werde gehen - Ick wer kai. ${ }^{33}$

Beranek received another piece of serious scientific material from Bertha W. Clark, explaining in detail the differences between German and the dialect of the Hutterites. Although they came from Switzerland, their dialect was different from Swiss German: "hearing the two Hutterite brothers talking reminds her as if someone wanted to talk with a hot potato in his mouth". ${ }^{34}$

Clark states that the dialect of the Hutterites copied their migration route, using words of French origin, and many Russian words (especially the older generation, the younger almost not understanding them).

Another impact was the integration of Mennonites into the Hutterite community during their stay in Russia, but their migration lines were different, across the Netherlands, Denmark, and Prussia. They brought many "Platt-Deutsch": "One of the preachers told me that he has to control himself during sermons, otherwise he would talk in Platt-Deutsch". 35

The communities in Sobotište and Leváre are also briefly mentioned: "I know that the Catholic descendants of the Hutterites live in Sobotište and Leváre. I know that one of the community houses built in the eighteenth century still stands. Have you established contact with these groups?"36

The letter contains more comprehensive interpretation of the dialectological specifics; a complete quotation is beyond the scope of this article, but Clark admits that she cannot name the differences between the groups because they will not be great, if they exist. She recalls that there are currently 3 groups and 26 colonies on the American continent. There are more significant differences in social culture (e.g., in choosing a spouse) or in clothing (using buttons or hooks on shirts). ${ }^{37}$

The last letters of the correspondence consists of two letters which are, however, substantially later in date (1943). The first is from Associate Professor Herbert Grau, who sends a brief dictionary of Habanic terms from the Great Levars to Beranek and explains their origin. ${ }^{38}$

The very last letter is just a brief report about the occurrence of two Haban courts in the town of Pezinok. ${ }^{39}$

\section{Origins and characteristics of the scientific collection the "German Archive"}

Because the material analysed is only a part of a much larger collection known as the "German Archive", it is appropriate to briefly describe it. The collection is part of the scientific collections of the Institute of Ethnology and Social Anthropology of the Slovak Academy of Sciences, which was established in 1953, the archives being built as a necessary part of the workplace, containing text, pictorial, and multimedia documents. The origin of the fund, called the German Archive, has not been sufficiently clarified. Most of it comes from the work

\footnotetext{
${ }^{33}$ German archive IESA SAS, $V$ - Habanerisch - 1932, Sudak, Johann Winter, document no. 51.

${ }^{34}$ German archive IESA SAS, $V$ - Habanerisch - 1932, Sudak, Bertha W. Clark, document no. 53.

${ }^{35}$ German archive IESA SAS, $V$ - Habanerisch - 1932, Sudak, Bertha W. Clark, document no. 53.

${ }^{36}$ German archive IESA SAS, $V$ - Habanerisch - 1932, Sudak, Bertha W. Clark, document no. 53.

${ }^{37}$ German archive IESA SAS, $V$ - Habanerisch - 1932, Sudak, Bertha W. Clark, document no. 53.

${ }^{38}$ German archive IESA SAS, $V$ - Habanerisch - 1932, Sudak, Herbert Grau, document no. 55.

${ }^{39}$ German archive IESA SAS, $V$ - Habanerisch - 1932, Sudak, Johann Weinzierhl, document no. 57.
} 
of the Beranek family in Slovakia in the so-called Institute for Homeland Research (Institut für Heimatforschung) in Kežmarok, and partially probably also from collections of the German Carpathian institute in Kežmarok (Karpatendeutsches Institut in Käsmark). The Carpathian Institute in Kežmarok was founded in 1941 and its ambition was to develop ethnographic research among the Carpathian Germans, as well as cultural and ideological work with this minority. ${ }^{40}$

With the changing situation on the front, to the detriment of the Third Reich, the activities of this institute ceased. Efforts to move and destroy archival records have led to part of the fund being lost or destroyed. How this fund got into the scientific collections of the Institute of Ethnology and Social Anthropology is subject to debate and unverified rumours. A former academic of the Ethnographic Institute at that time, Associate Professor Emília Horváthová (employed 1951-1975) stated that these materials were found in the hangar at Piešt'any airport after the Second World War. ${ }^{41}$

Apart from the occasional research interest of the employees of the then Ethnographic Institute and the Museum of the Carpathian Germans, this archive collection was intact. There were several reasons why nobody tried to process it for so long: unclear origin, the (apparent) absence of any inventory or index, and the difficulty of composition and completeness. Last but not least, many documents were very difficult to read, being written in gothic German script, archaic manuscript, or damaged.

The first attempt was made in 2011, when a researcher at the Institute of Ethnology and Social Anthropology of the Slovak Academy of Sciences, Mgr. Zuzana Panczová, PhD, in her research on an ethnic group of German lumberjacks in the Little Carpathians called Huncokari by the majority, processed thirty archival units from the section Slowakische Volkserzählungen (Slovak Folk Tales), dated 1930-1932. It emerged that these sources were directly linked to the research of German enclaves, which German ethnographers had been actively interested in, and this research had later been subordinated to the political objectives of the Third Reich. ${ }^{42}$

In 2018, employees of the Institute of Ethnology and Social Anthropology of the Slovak Academy of Sciences proceeded to catalogue the archive and discovered a report written by Svetozár Švehlák and Milan Leščák in 1966, stating that the state of the archive did not correspond to that of 1943 and that it was most likely a private archive only supplemented by IHF research. Most of the collection is composed of dialectological and folkloristic material classified by topic and questionnaires, marked with Roman numerals. However, there are also fragments of research of folk medicine, architecture, viticulture and, of course, exclusively private material-personal correspondence.

The Haban part of the fund is marked "V". In the report it is briefly characterised as follows: "Another part of the materials consists of linguistic (dialectological) collections, which are mostly untranscribed and unsorted, e.g., from the Haban research."

This characteristic, as the authors themselves, admit, is considerably superficial, because only the Haban part contains other materials in addition to direct research questionnaires and notes. Since there is no other catalogue of this archival collection apart from the cursory list of file folders marked by Roman numerals, employees of the Institute of Ethnology proceeded to catalogue it within an academic project: "History of Ethnology in Slovakia in the 20th Century: Ethnological Research of the German Minority”. However, as I pointed out, many are damaged,

\footnotetext{
${ }^{40}$ LOZOVIUK, Etnicita..., p 17.

${ }^{41}$ PANCZOVÁ, Pôsobenie Franza J. Beranka..., p. 35.

${ }^{42}$ PANCZOVÁ, Pôsobenie Franza J. Beranka..., p. 24.
} 
unlabelled or mislabelled, or absent. In short, when the fund came into the possession of the Institute of Ethnology, it was incomplete and in a catastrophic state, which was undoubtedly due to its movements in turbulent times. The aim of processing therefore remains to explore the fund and create a catalogue that will allow its further scientific processing.

As the collection is thematically and genre diverse, it was necessary to develop a registration system that would allow the cataloguing of documents that have no name or have a supporting character (notes, excerpt cards). An electronic catalogue is currently being built, where the following items are recorded for each document:

1. Signature of the file-the original signatures that are listed in the report from 1966 by Svetozár Švehlák and Milan Leščák. In cases where the file does not have a number, this signature is assigned chronologically after consultation with other project solvers (to avoid double numbering and subsequent confusion in cataloguing). The Haban file is marked with a Roman numeral "V".

2. Title of the file-listed if it exists, in this case with the name "Habans".

3. Author of the document-first surname and then name.

4. Serial number of the document within the file-assigned by the worker who catalogues the document in chronological order.

5. Original signature of the document - to be indicated if the document has such signature. This information is used for later accurate identification of the document if it is linked to another document in another file. Part of the files are broken (or incomplete) due to the difficult circumstances of the acquisition of the fund, and this signature is intended to assist in their identification (and possible completion).

6. Document title in the original language-only stated if the document has a title.

7. Dialect—with regard to the scientific focus of Professor Beranek, it is also necessary to indicate the dialect in which the document is written. This information is provided only if the dialect can be identified with certainty.

8. Title of the document and translation-if the document has a title, it shall be stated in the Slovak language; if not, the researcher may assign a concise title according to its content at their discretion.

9. Document genre- this entry is only included in cataloguing if the genre is unambiguous, e.g. "fairy tale".

10. Document dating - stated only if the document is dated or can be dated from another related document.

11. Regesta - the researcher briefly describes what the document is about or what it discusses. In cases where the researcher has assigned the title of the document because it did not exist, the description may be identical to that title.

12. Municipality - the historical name of the municipality from which the document originates is stated in the German language.

13. Municipality, present name-the current Slovak name of the municipality from which the document originates or to which it refers.

14. Country - current state in which is the municipality from which the document originates or concerns. This information is provided in the Slovak language.

15. District - the current district, or territory that includes the municipality mentioned in the documents. In the case of foreign municipalities, the district may be replaced by another 
geographical specification (county, republic, region, etc.), but this must be specified. This is an additional indication that specifies the localisation in the event that there are municipalities with the same name.

16. Note-this will include any other relevant information concerning the document, e.g. discrepancies, illegible passages, or reference to related documents.

17. Interesting fact (optional) - it is possible to mention or emphasise any particularity or interesting fact of an individual document which could be of interest to other researchers (e.g. the signature or stamp of an important person, the order for a significant historical event, etc.)

So far, this is an electronic cataloguing scheme that can be changed (or supplemented) with continued cataloguing, as it is not yet fully known what the fund contains.

\section{Conclusion}

The original inspiration to write this contribution to the study of Habans was the fact that at least in Slovakia this chapter is closed. The Habans either emigrated or merged with the majority and all that still catches the attention of scholars is Haban ceramics, whether in terms of art, museology, or ethnography. If we look at the efforts of Franz Beranek to collect and create a dialectological atlas of German enclaves and if we understand this as an experiment, I must say that it failed.

The reason for this was that what he was trying to prove simply did not exist. ${ }^{43}$ The bearers of the language died out and it is therefore impossible to say that the Habans in Slovakia used a single dialect. It is much more likely that it was a set of different but related dialects. The theory of original, pure German has also proved to be misleading, which Beranek himself reflects in his work:

Caution should be exercised when assigning the names of the Haban immigrants who came to our territory in the sixteenth and seventeenth centuries. There are many forms of place names found in the books of this sect or in the dialects of the remaining Habans in the Vel'ké Leváre and in Moravský Svätý Ján, apparently taken directly from the mouth at a given time, though often only as used by a minority of the existing medieval German population" In addition, their script contains many young or new, many times only superficially Germanised names of Slovak and Hungarian towns, which were hardly the common property of all speaking in the Haban dialect, because in most cases they can no longer be proved. For the sake of completeness, these forms of names, if the city is listed for other reasons, are listed together. In addition, we are given in writing some nice German-sounding, at first glance truly antique-like names of cities, which, although perhaps only in connection with a foreign form, were discovered by the Habans: Freischütz (Sobotischt; probably based on the Hungarian szabad "frei”), Neusorg (unclear whether Katow, Holitsch/Holíč, Popudin/Pobedím or Brodsko). ${ }^{44}$

\footnotetext{
${ }^{43}$ This was a quite common result of scientific projects and expeditions in the Third Reich due to their subordination to political goals.

${ }^{44}$ BERANEK, Franz. Die deutsche Besiedlung des Preßburger Großgaus. Munchen, 1941, pp. 13-14.
} 
The main asset of Beranek's research remains at least a brief documentation of the linguistic and ethnographic remnants of the Habans in Slovakia and their comparison with similar communities abroad. However, it is still an open question and cataloguing of this archive is still ongoing and it is possible that further processing will bring new knowledge in this area.

\section{References}

Archival scources:

German archive of the Institute of Ethnology and Social Anthropology of the Slovak Academy of Sciences, Haban Part - no. V

\section{Literature}

BERANEK, Franz (1941). Die deutsche Besiedlung des Preßburger Großgaus. Munchen.

ČERNOHORSKÝ, Karel (1931). Poćátky habánskyych fajansí. Opava.

FAUST, Ovidius (1933). Zo starých zápisnic mesta Bratislavy. Bratislava: Universum.

KALESNÝ, František and SZABÓ, Tibor (1981). Habáni na Slovensku. Bratislava: Tatran.

IRŠA, Rudolf and PROCHÁZKOVÁ, Mária (1987). Habáni vo Vel’kých Levároch. Sprievodca dejinami habánov a habánskeho dvora vo Vel'kých Levároch. Skalica: Záhorské múzeum.

KALMAN, Weiser (2018). "One of Hitler's Professors": Max Weinreich and Solomon Birnbaum confront Franz Beranek. In: Jewish Quarterly Review 108, pp. 106-124.

LOZOVIUK, P. (ed.) (2012). Etnicita a nacionalismus v diskursu 20. století. Brno.

PANCZOVÁ, Zuzana (2017). Pôsobenie Franza J. Beranka na Slovensku v 30.a 40. rokoch 20. storočia: výskum „Huncokarov“a Institut für Heimatforschung. In: Ethnologia Europae Centralis. Trnava.

SCHVARC, Michal (2013). „Kulturraub“ alebo záchrana kultúrneho dedičstva? Evakuácia archívov a kultúrnych pamiatok nemeckými orgánmi zo Slovenska koncom 2. svetovej vojny. In: Muzeológia a kultúrne dedičstvo, vol. 1, 2013, Is. 1, pp. 75-82. ISSN 1339-2204

\section{Internet sources:}

https://mennonitehistoricalsociety.org/about/ accessed 25 September 2019.

Gloal anabaptist memnonite encyclopedia online (GAMEO: https://gameo.org/index. php?title=Friedmann,_Robert_(1891-1970) accessed 25 September 2019.Encyklopedia Beliana. Bednárik, Rudolf [online]. Encyclopaedia Beliana, ISBN 978-80-89524-30-3. [cit. 2020-03-31]. Dostupné na internete: https://beliana.sav.sk/heslo/bednarik-rudolf 